\title{
Let's understand the position of academic libraries in views of different users
}

\author{
S. L. Jadhav \\ Librarian, N.E.S. Science College, Nanded, Maharashtra, India \\ *Corresponding Author: S. L. Jadhav \\ Email: jadhavscnlibrary@gmail.com
}

\begin{abstract}
This paper attempts to understand the position of academic libraries in views of different users include stakeholders, employer and service providers. Academic libraries have gone through computerization and then are practicing use of ICT. While functioning they are tackling variety of issues at a time and thus it has resulted it some confusion and difficult stage. Focusing on these issues few questions were asked to the experienced librarians and then views of different groups are discussed in the paper. Knowing difficult issues recommendations are suggested. There is need to counsel different user groups particularly students group is recommended in the paper.
\end{abstract}

Keywords: Academic libraries, Users, Teaching and non-teaching staff and Library staff etc.

\section{Introduction}

Role of academic libraries in catering need of users especially in higher education is of vital. In India effective beginning of systematic development of academic library services was started after 1950 onwards. Initiation and slow journey of computerization and then ICT made control over libraries. Academic libraries remained ahead in revolution. However since a decade situation of academic libraries has changed a lot. It has become issue of rethinking. As I am in library profession for more than 25 years, I have experienced both i.e. computerization and then application of IC. Further accordingly author thought and gathered opinions of library professionals, faculty and student users about present position of academic libraries. Ten core general questions about different views were asked to them and discussed in this paper. Fundamental objectives of this paper were to know the present position of academic libraries and suggest remedies over it.

Well known experienced library expert Khanna called 'Academic libraries' are the pulsing hearts. Further Gour Babita (2015) says college libraries not only merely to house and circulate library material but to supplement and extend the teaching process with service offered faculty members library opportunities for improving functions and to encourage students to read more and better books.

\section{Factors responsible for decline status of Academic libraries}

Impact of ICT: Information and Communication Technology (ICT) has made great revolution in every field of human life. Libraries have remained forefront in securing benefits of ICT. It has become possible to discharge information on fingertips and that too at users destination within no time. There is no doubt and space to put negative remark to ICT. Each of us has embraced the entry and use of ICT. Present reference section has been replaced by database browsing labs. Libraries have been making optimum use of ICT in rendering variety of services and accessing of information. Today no library can prove well functioning in absence of ICT.
But at the same time use of reading rooms are declining day by day. Strength of users particularly of students is coming down. Same is happening in respect of faculty. They prefer to use internet for direct access of needed information sources for teaching and research purpose. This has made the approach narrow and to the point. Because of this specialization is improving but wide and through knowledge about concepts or related aspects remains poor. General observation shows that internet has been making the image of teachers poor as they are more dependent on it. This approach affects on teaching performance. Teachers are not reading books and other related references in details as they used to before a decade or two. Approach towards internet is admirable for fast access of information that does not mean that thorough and serious reading is not required. In fact, it is the absolute correct method of studying. There is urgent need to understand importance and value of serious, silent and focused reading after detailed browsing of literature on rack or in database personally. Browsing of literature has its own importance in enriching knowledge of readers.

\section{Changing views of different users about academic libraries \\ Academic libraries in views of Students}

Nowadays students do not bother about use, importance and role of library in their career. They find notes received in the class from their teachers are more than enough for passing examinations and securing marks. Understanding of subject, association with other subjects, basic concepts, its applications are not considered. And thus, subject knowledge remains poor. Even after given orientation they purposefully neglect use of library resources. Respect and place of library in their view is just ordinary and casual. Reading culture is fading consistently. This situation has become great challenge for academic libraries. There is need of focused and proper counseling of students so they will realize value of effective use of library. 
Academic libraries in view of Faculty/Teachers

With huge impact of ICT faculty members are accessing information on internet at their destination with the help of android phones and tabs as these electronic devices are found handy and convenient for use.

Current scenario shows that faculty members remain busier in extra activities and thus work of teaching gets affected and use of library is declining consistently. Survey of reading habits of teachers shows that many a times they are unable to direct students towards scholarly literature in their respective subject areas because they have not remained regular visitors of libraries. To overcome this problem it should be mandatory to visit, browse and print an online subject literature provided in authentic databases. Reinstituting the culture of reading is needed first for faculty and then they should take initiative in counseling the students. In fact it should be the more responsibility of faculty to increase student users of library than the library staff.

\section{Academic libraries in the views of Non-Teaching staff}

Non-teaching staff always feel that they have lot of work in office and departments and they are getting less salary in comparison to the librarian and even the assistant librarian. Besides their perceptions about library staff shows that there is less and easy work in the library. i.e. only issue and collect of books and periodicals. In general non-teaching, particularly administrative staff prefers to remain in close association with the principal than the teaching staff. Relations between principal and office are closed as they are dependent vice versa. Adjustment and favorable changes as per their convenience are the common practices for nonteaching staff and the principal.

Because of this attitude most of the teaching staff and library staff gets separate, neglected and feel insecure. This juncture of feeling leads to negativity and thus they show less attachment towards their duty. Further it creates space to oppose and criticize authority, non-teaching, even management and whole system. Therefore to overcome this difficulty non-teaching staff also requires counseling. Here principal's role is very important. He /she should clarify things related to their posts, nature of work, pay scales and ensure unity, brotherhood and harmony.

\section{Academic libraries in views of management authority}

In general most of the management authority and members do not take keen interest in college functioning. They feel that the institution functions well and thus further they feel happier and more comfortable whenever some activities are going on, special functions organized frequently, staff and students gathered in huge numbers, news publish through different medias. They fully trust on the Principal and assume everything is going.

Management authority and members should understand that only keeping principal's office clean, neat and well equipped is not the indication of good quality. In fact bench mark to judge and put remark that the college is functioning well and improving quality or not should be in this sequence i.e. First library, Laboratories, Classrooms, Principal's office and Office. Management should visit library and all departments at least few times every year and should interact with staff with the intention of developing healthy relations and motivate staff to work more

\section{Academic libraries in the views of Library staff}

Approach of library staff is also coming down. They are in confused state. They simply blame system saying that users especially students visit library during examination period to borrow books and it is the fact that many students tear pages of library books. Present status of library staff has become helpless and unable to stop bad attitude of students as there is no proper support and cooperation from faculty and authority. This is the real picture of maximum academic libraries at college level. Therefore there is need to insure good cooperation, integration, feeling of togetherness for improvement of overall development understanding library as the base. Library staff should their sincerity, consistency in working, initiative in learning and acquiring new skill of ICT along with due importance of traditional collection and maintenance this all

\section{Conclusion and recommendations}

1. Present status of academic libraries seems to be in confusing stage. Use and status of library in views of stakeholders, service providers, authority and library staff is different. Library staff are unable to understand and suggest appropriate solution to these issues.

2. There is need to counsel users particularly to student group on priority basis.

3. Faculty should take initiative and responsibility of using and understanding importance of library in making career.

4. Non-teaching staff should accept library staff as family members and give equal importance.

5. Principal should study library in detail and then make necessary changes.

6. Management authority should visit library at least 3times in a year and interact with them and assure them that their role is as important as faculty.

Kindly put your opinions about present status of library if your library is computerized and using ICT.

Q. 1. Do your users visit library? Yes / No

Q. 2. On which aspect they prefer to interact?Syllabus books/ Books of competitive Exams / General Books / Periodicals / e-Resources

Q. 3. How is the status of your library functioning? Good / Excellence/ poor

Q. 4. Do you face any difficulties in functioning library ? Yes / No

Q. 5. Do you need some help to run library well ? Yes / No

Q. 6. Are you comfortable while working in library? Yes/ No

Q. 7. Do you like to suggest something new for improvement of library? Yes/No 
Q. 8. What is your opinion about users specially students?

\section{Using maximum / Using poor.}

Q. 9. Do teachers frequently recommend books for library? Yes / No

Q. 10.Do the students users are satisfied with library facilities? Yes / No

\section{Conflict of Interest}

None.

\section{Source of Funding}

None.

\section{References}

1. Khanna J K (1987), Library and Society, $2^{\text {nd }}$ Rev. ed. New Delhi, Ess Ess Publications. 1987; I-XXIV.

2. Jeevan V K J, E - Resources and digital services. New Delhi, Ess Ess Publication. 2011.

3. Mittal RL, Library administration. $5^{\text {th }}$ ed. New Delhi, Metro Politian Book Co. Pvt. Ltd. 1984.

4. Sharma R, Indian Academic Libraries \& Dr. S. R. Ranganathan: A Critical Study, New Delhi, Sterling. 1986:123

5. Babita G. in his paper entitled 'information literacy and effective use of academic library 'University News 2015;52(47)23-9.

How to cite: Jadhav SL. Let's understand the position of academic libraries in views of different users. IP Indian $J$ Libr Sci Inf Techno 2020;5(2):65-7. 